\title{
Street children, human trafficking and human security in Nigeria: competing discourses of vulnerability and danger
}

\author{
Joshua Oyeniyi Aransiola ${ }^{1,2}$ and Christina Zarowsky ${ }^{1}$ \\ ${ }^{1}$ School of Public Health, University of the Western Cape, Cape Town, South Africa. \\ 2 Sociology and Anthropology Department, Obafemi Awolowo University, Ile - Ife, Nigeria
}

\begin{abstract}
This paper examines the lived experience of street children and other stakeholders' perceptions in three urban cities (Lagos, Kaduna and Port Harcourt) in Nigeria. The study used quantitative and qualitative methods to explore the perspectives of five major stakeholders: Government Agencies, Civil Society Organizations, the Community, Non-Governmental Organizations (NGOs) and street children themselves. The findings revealed that street children are perceived to be perpetrators as well as victims of crime. They are exploited, abused and used as drug mules, pressed into commercial sex, and manipulated or bribed into the fire-bombings and violence in Nigeria. While some stakeholders urge increased protection of child rights, others canvassed for "eradication" of the street children. There is therefore the need for more pragmatic steps by the Nigerian government and civil society to address the conditions faced by street children in order to address the security problems and the fundamental human rights of the children.
\end{abstract}

Keywords: Street children, children' rights, abused children, child trafficking, urban violence

\section{Résumé}

Ce document examine l'expérience vécue par les enfants des rues et les perceptions des autres parties prenantes dans trois villes urbaines (Lagos , Kaduna et Port Harcourt) au Nigeria. L'étude a utilisé des méthodes quantitatives et qualitatives pour explorer les perspectives des cinq principaux acteurs : organismes gouvernementaux, des organisations de la société civile, la communauté des organisations non gouvernementales (ONG) et les enfants des rues eux-mêmes. Les résultats ont révélé que les enfants de la rue sont perçus comme étant les auteurs ainsi que les victimes d'actes criminels. Ils sont exploités, maltraités et utilisés comme passeurs de drogue, pressés dans le commerce du sexe, et manipulés ou corrompus dans le feu attentats et des violences au Nigeria. Alors que certains intervenants demandent une protection accrue des droits de l'enfant, d'autres sondés pour "éradication» des enfants des rues. Il ya donc la nécessité de mesures plus pragmatiques par le gouvernement nigérian et la société civile pour faire face aux conditions rencontrées par les enfants de la rue afin de résoudre les problèmes de sécurité et les droits humains fondamentaux des enfants.

\section{Introduction}

Street children, human trafficking, and security threats are global problems attracting concern at both national and international levels. Le Roux (1996) observed that the phenomenon of street children occurs worldwide across cultural boundaries, while the social backgrounds of street children are remarkably similar. Human trafficking is ranked the world's third largest crime (Dave-Odigie, 2008; Keefer, 2006) and developing countries serve as origin, transit and destinations while the developed countries are major destination countries. While many studies have been conducted on street children and possible solutions suggested (Aransiola \& Agunbiade, 2009; Aransiola, Bamiwuye, Akinyemi, \& Ikuteyijo, 2009; UNICEF, 2007), many authors have also linked the problem of street children to human trafficking crime within national boundaries of many countries as well as across international boundaries (Clark, 2003; Fitzgibbon, 2003; Fitzpatrick, 2002).

In response to growing international concerns about the abuse of children's rights and human trafficking, there are many United Nations Conventions which condemned child abuse including trafficking in all its forms. These include the Forced Labour Convention, 1930, the United Nations Supplementary Convention on the Abolition of Slavery, the Slave Trade, and Institutions and Practices Similar to Slavery, 1956, and the Convention on the Rights of the Child, 1989. Others are the UN Protocol to Prevent, Suppress and Punish Trafficking in Persons, Especially Women and Children in 200I and the Worst Forms of Child Labour Convention, 1999 (United Nations (UN), 1957a, 1957b, 1989, 1999,

I. Corresponding author: Dr. Joshua O. Aransiola, Sociology and Anthropology Department, Obafemi Awolowo University, Ile-Ife, Nigeria. Email: aransiola2@yahoo.com, aransiolajo@gmail.com, Phone: +234-703-I I7-0279 or $+27-73-010-9875$ 
200I). The essential elements of child labour as listed in article 3 of the Worst Forms of Child Labour Convention 1999 include: sale and trafficking of children, debt bondage and compulsory recruitment of children for armed conflict, use, offering or procuring of a child for prostitution. Others are use of children for illicit activities such as drug trafficking and other works that are likely to harm the health, safety or morals of children. Article 7 of the Convention reiterated the need for member states to ensure effective implementation and enforcement, including the provision and application of penal sanctions or, as appropriate, other sanctions.

In line with the international conventions, Nigeria enacted the Child Rights Acts 2003 and the 'Trafficking in Persons Prohibition and Administration' Act 2003 (Federal Government of Nigeria, 2003; Federal Republic of Nigeria, 2003). These laws give the law enforcement agents a much-needed legal framework for rescuing victims, and for investigating, arresting, and prosecuting traffickers. For instance, National Agency for Prohibition of Trafficking in Persons (NAPTIP) Act Section 50 refer to trafficking as "all acts and attempted acts involved in the recruitment, transportation within or across Nigerian borders, purchase, sale, transfer, receipt or harbouring of a person involving the use of deception, coercion or debt bondage for the purpose of placing or holding the person, whether or not in involuntary servitude (domestic, sexual or reproductive), in forced or bonded labour, or in slavery-like conditions." In addition, the act for the first time instituted severe penalties for the offence of human trafficking ranging from two years imprisonment for commercial carrier of persons in section 29 (I) to life imprisonment for exportation of any person in Nigeria for slavery or slavery like purposes (Section II, 23 and 24). It also allows confiscation of properties of convicted traffickers and accomplices and make penalties for trafficking offences related to sexual purposes and involving minors under the age of 18 much stiffer than other penalties in Section 19 (I). The new laws also led the way for the creation of NAPTIP, a government agency that disseminates preventive information to the public, educates police officials, and monitors trafficking cases while UNICEF supported the institutional development of NAPTIP, helped to train immigration and police officers, and provided necessary equipment (UNICEF, 2005). Several arrests have been made and many prosecuted for child trafficking since the creation of the Agency in Nigeria but this does not reduce the incidence of trafficking especially child trafficking.

Despite increasing efforts at local, national and international levels, the problem of street children and human trafficking has proved particularly resil- ient to remedial action. In Africa and especially the West African sub-region, Nigeria remains an important country of origin, transit and destination for trafficking in human being(Ojukwu, 2006; UNESCO, 2006). This paper draws on extensive empirical research on street children in major cities in Nigeria that suggests that links between high numbers of street children and human trafficking in Nigeria are contributing to both objective and perceived insecurity at both national and international levels. In the process, the fundamental rights of the children themselves are at risk of being lost to view and hence further violated. This study is therefore important in order to help our understanding of the intricacies surrounding the street children as both perpetrators as well as victims of crime in Nigeria

\section{Theoretical framework}

The theoretical underpinning to this is guided by a combination of lifestyle activity and strain theories. While strain theory helps to understand why street children may involve in crime and indulge in some anti-social lifestyles as a way of coping with their stressful conditions, lifestyle activity theory explains how such lifestyles may subject street children to crime victimizations.

Strain theory argued that strains or stressors create emotional pressures which may lead to various anti-social behaviours including crime. For instance, stealing the money you desire or illicit drug use to alleviating negative emotions (Agnew, 200I). Agnew (200I) argued that there are four basic characteristics of strains that could lead to criminal behaviours. These include when the strains " $(I)$ are perceived as unjust, (2) are seen as high in magnitude, (3) are associated with low social control, and (4) create some pressure or incentive to engage in criminal coping". Strainful events may be perceived as unjust when the victims believed that it can be attributed to voluntary or intentional behaviour of others. It could be seen as having a high magnitude when the perceived costs of noncriminal coping is higher than criminal coping or when the emotional noncriminal coping is less effective or more difficult. The strain could also reduce the ability to cope due to depression. Strain could also be associated with low social control when it is caused by erratic parental discipline, parental rejection or homelessness since those who lack conventional attachments usually lack social supports or resources to cope in noncriminal manner. This argument is relevant to street children in particular since many of them results to street life due to lack of adequate family supports or they suffer abuse within the family (Oloko, 1999). 


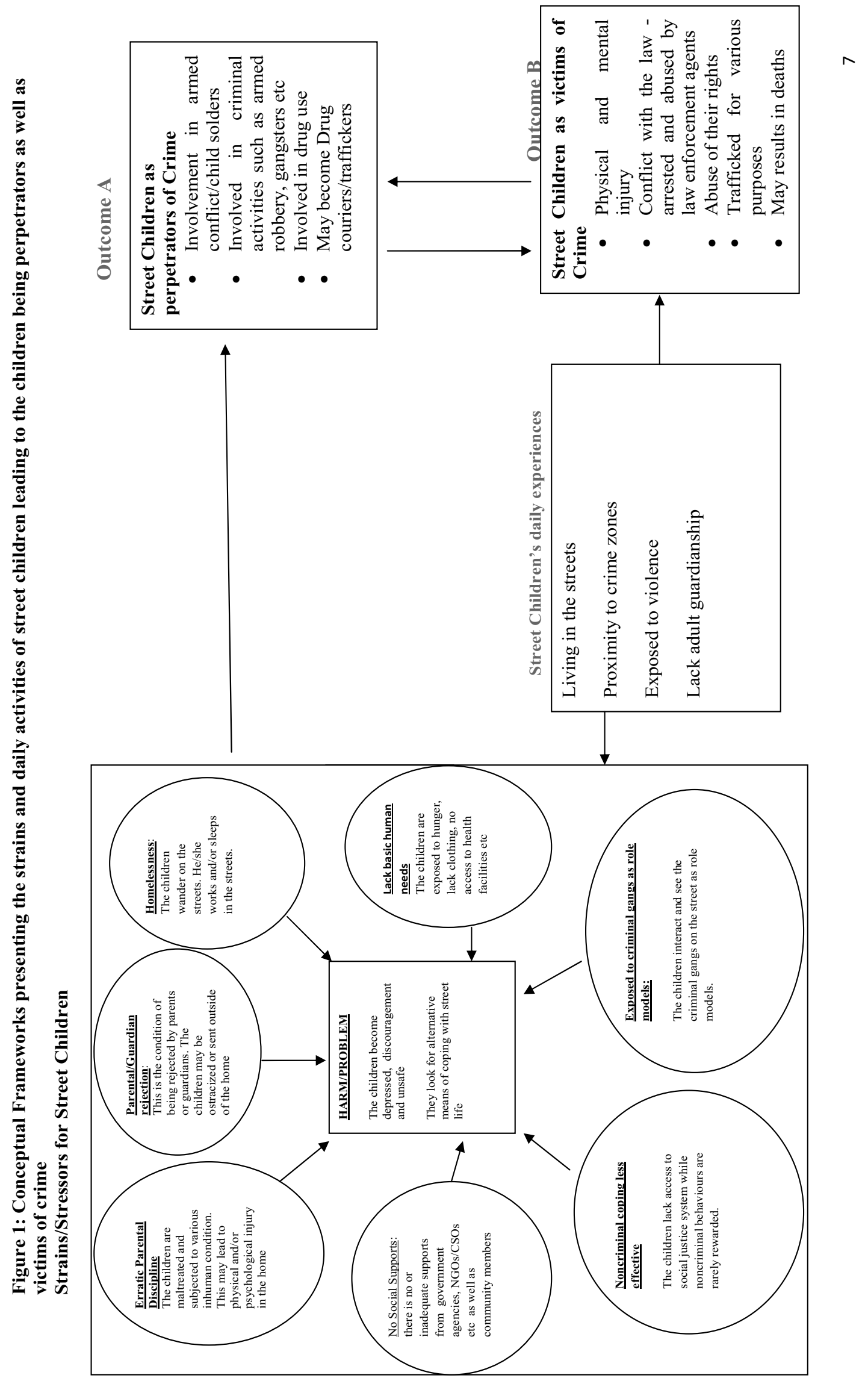


Some strains create pressure or incentive to criminal coping when they are "associated with exposure to others who model crime, reinforce crime and/or present beliefs favourable to crime" (Agnew, 200I). A good example of this is when a child is being bullied by peers and violence seems to be the only effective way to respond to it. Street children by the virtue of their conditions are often live in high crime zone in the inner city thereby influencing their beliefs about criminal coping.

\section{Street children as perpetrators of crime}

Lifestyle activity theory posits that what people do, how they behave or where they live places them at more risks of criminal victimization. According to Hindelang, Gottfredson, and Garofalo (1978) and Cohen and Felson (1979), individuals' daily routine activities/behaviours can help to explain how people avoid or suffer many other misfortunes. For instance, individuals frequent at bars, social clubs and other public places outside home where guardianship capacity is low and proximity to potential offenders is high are more likely to be victims of crime than those who do not (Sampson \& Lauritsen, 1990). Also, the community context and spatial structure of routine activities and opportunities may play important roles in determining the rate at which individuals or group of people become victims of crime. Persons living in densely populated urban area close to crime zone therefore are also potential victims of crime than those who live in more secured areas. Hence, the street children by the fact of their daily routine activities carried out on the streets with some of them being homeless and without adult's guardianship are potential victims of various kinds of crime including human trafficking. The two theories therefore help us to see the two sides of the coin by uncovering the intricacies involving the street children as perpetrators as well as victims of crime.

\section{Rationale for the study}

In Nigeria, Oloko (1999) and Ahiante (2004) noted that street children are found in nearly all public places across Nigeria's major cities and are thus perceived to be "all over the place", in the markets, at bus stops, car parks, garages, street corners, under the bridges. The population of street children appears to be on the increase, based on surveys in selected cities (Aderinto, 2000; Araoye, 2006; Oloko, 1999). However, no comprehensive census or survey of street children has been undertaken in Nigeria. The sight of street children sometimes infuriates and frightens community members, but their plight also invokes sympathy and compassion (Bourdillon, 200 I). It therefore becomes pertinent to ask.
How are street children perceived by different stakeholders in Nigeria? And how do these children experience their lives, communities, and social support? The study reported here sought to understand the intricacies surrounding their vulnerabilities and the threats their existence is perceived to pose to community members as well as Nigeria as a nation. The study objectives include:

I. Examination of street children's experiences in selected Nigerian urban communities and the supports they receive from different stakeholders

2. Understanding how the children are perceived with respect to being perpetrators as well as victims of crime in the country.

\section{Methods}

\section{Study settings}

The study was carried out in the cities of Lagos, Kaduna and Port Harcourt, which are three of the main cities where street children are largely concentrated in Nigeria. The selected cities reflect the three of the main urban centres located in different geo-political zones of the country and most of the Non-Governmental Organizations (NGOs) working with street children are also concentrated in these cities. Lagos, which is the commercial heart of Nigeria, is located in the south west. Kaduna as the capital of the former Northern region is also one of the important commercial centres in the region and Port Harcourt is the heart of the oil industry, the source of most of the nation's foreign exchange earnings. There are concentrations of street children across all the three cities selected for this study.

\section{Data collection}

In each of these towns, five different categories of respondents were included: Government Agencies, Civil Society Organizations, the Community and Non-Governmental Organisations (NGOs): and street children themselves. Both quantitative and qualitative techniques were employed to collect the primary data in this study. We interviewed 500 children with the assistance of trained field workers in each city using self-administered structured questionnaires. Two locations where the street children were concentrated were purposively targeted in each city with the assistance of some NGOs working with the children and both convenience and snowballing sampling techniques were employed to select the respondents in each location due to lack of sampling frame. Thus all street children who were available and voluntarily accepted to participate in the study were interviewed until the desired number 
was reached. Three NGOs were purposively selected based on the programmes they have for the street children and completed semi structured interview in each of the three cities. At least one official of the Social Welfare Departments and three Civil Society opinion leaders (e.g. Imam, church leader, lawyer) were included in each of the study city. Six (6) Focus Group Discussions were finally conducted with the following social categories of community members - Opinion leaders (Imale and Ifemale groups), Adult males and females (2 separate groups), and Youths (Imale and I female groups). Each FGD included between 8 and 12 participants. The children were informed of their rights to refuse participation while verbal consents were obtained from those who were willing to participate. Voluntary individual informed consent was obtained from all other participants. All informed consent documents, audio recordings and transcripts were kept under lock and key at the study site and anonymity of the participants were guaranteed. Ethical clearance was obtained from Obafemi Awolowo University Research Committee.

\section{Data analysis}

The quantitative data collected were analyzed with the use of SPSS computer software. The use of ANOVA was employed to compare the mean levels of supports received by the street children of various social descriptions. Qualitative data collected using key informant interviews (KIIs) and Focus Group Discussions were analyzed using content analysis carried out with the help of the Text Base Beta Computer software, which helped in sorting out the data thematically while report was presented through triangulatory process.

\section{Results}

\section{Socio-demographic characteristics of the street children}

We define street children as children who either work or live on the streets. Our study distinguished between children "on the streets", who return to their own home or another adult's home daily, and children "of the streets" who live alone or with other children in the open or in informal housing. Children "on the streets" work in the streets to support their families. A slight majority of our sample lived with their families; nearly half lived in the streets. Among the children 'of' the streets, most had previously been children 'on' the streets. As the summary results show, about half of the children came from families with only one parent, but the other half came from "intact" families which never- theless were unable or unwilling to provide shelter for these children.

As this was a (large) convenience and snowball sample, we cannot speak with confidence about the overall population of street children in Nigeria. In our sample, however, most children were older between 15-17 - but the mean age was 14. There were very few children under 6 . Most street children (83\%) were males.

The characteristics and histories of the children differ across the three cities. In the Islamic North (Kaduna), most children were not in formal education, and many reported running away from koranic schools. There were relatively few girls in the Kaduna sample - the problem that girls face in the North is forced early marriage (before the time of their first menses at age 10-I 3years (Makinwa-Adebusoye, 2006). The highest proportion of girls was in Port Harcourt, in the oil-rich Niger Delta. Street children in Lagos come from all over the country as this is the commercial centre. Both families and individual children migrate to Lagos; crowded informal housing is more common; and precarious livelihoods are very common.

Most children did not know about their family income, but those who did reported very low incomes. The children's mean income per week (65I.89 Naira) also shows that the children are living in abject poverty in the street. The majority of parents were reported to be in informal employment (farming 42.2\%, trading $16.3 \%$ and artisans $15.8 \%$ ) though there were also lower cadre civil servants among the parents and one banker.

Data on the educational level of the street children indicate that $26.7 \%$ dropped out of primary school while $26.2 \%$ dropped out of secondary school. Also, 23.5\% completed primary school education while $21.5 \%$ did not have any formal education. However, in Kaduna, 46.2\% of respondents had no formal education. The street children's religious affiliation shows that $47.5 \%$ were Christians while $48.3 \%$ were Muslims. Majority (87.6\%) of the respondents in Kaduna were however Muslims while the majority (59.2\%) of the respondents in Lagos and $71.4 \%$ in Port Harcourt were Christians. This is in line with the religion that dominates in each of the regions selected for this study.

About half (50.6\%) of the respondents' parents were married while the other half falls into various marital statuses: Widowed (16.5\%), both dead (10\%), divorced (9.8\%) and separated (9.3\%). Similarly, a little above half (54.1\%) of the respondents parents live together, $16.9 \%$ live separately while $28.9 \%$ of the respondents have lost touch with the parents and therefore did not know their present living arrangements. Also, $51.5 \%$ of the respondents' 
parents were into monogamous marriage while the remaining $48.5 \%$ were into polygynous marriage. The type of houses parents of street children live shows that majority of these parents either live in a single room (34.3\%) or in 'a room and parlour' apartment (45.5\%). In Kaduna, at least 2 out of every 10 street children's parents live in a single room (23.0\%) while 6 out of 10 live in 'a room and parlour' apartment (63.8\%). In Lagos, $45.0 \%$ of the respondents' parents live in a single room while $36.0 \%$ expressed that their parents live in a room and parlour. Also, $34.8 \%$ and $36.8 \%$ of the respondents' parents in Port Harcourt live in a single room and a room and parlour apartments respectively.
The number of children ever born by respondents' parents was considered. Majority (76.0\%) had more than 4 children. The distribution shows that $30.4 \%$ in Kaduna, $10.0 \%$ in Lagos and $31.6 \%$ in Port Harcourt of their parents had less than 4 children. In comparing the number of children ever born by respondents' parents and the type of house they live, it is evident that there is problem of overcrowding in most homes which produced these street children. The study data shows that the mean number of children in these homes is 6.48 . Table I shows the detail socio-economic characteristics of the street children selected for this study.

Table I Percentage distribution street children's socio-economic and demographic characteristics by city of residence

\begin{tabular}{|c|c|c|c|c|c|c|c|c|}
\hline \multirow[b]{3}{*}{ Age in Years } & \multicolumn{6}{|c|}{ Town of Residence } & \multirow{2}{*}{\multicolumn{2}{|c|}{ Total }} \\
\hline & \multicolumn{2}{|c|}{ Kaduna } & \multicolumn{2}{|c|}{ Lagos } & \multicolumn{2}{|c|}{ Port Harcourt } & & \\
\hline & $\mathbf{N}=\mathbf{5 0 0}$ & $\%$ & $\mathbf{N}=\mathbf{5 0 0}$ & $\%$ & $\mathbf{N}=\mathbf{5 0 0}$ & $\%$ & $N=\mid 500$ & $\%$ \\
\hline Less than 6 years & - & - & 01 & 0.2 & 14 & 2.8 & 15 & 1.0 \\
\hline $6-15$ years & 263 & 52.6 & 274 & 54.8 & 311 & 62.2 & 848 & 56.5 \\
\hline Above 15 years & 237 & 47.4 & 225 & 45.0 & 175 & 35 & 637 & 42.5 \\
\hline \multicolumn{9}{|l|}{ Sex } \\
\hline Male & 467 & 93.4 & 432 & 86.4 & 348 & 69.6 & 1247 & 83.1 \\
\hline Female & 33 & 6.6 & 68 & 13.6 & 152 & 30.4 & 253 & 16.9 \\
\hline \multicolumn{9}{|l|}{ Educational level } \\
\hline $\begin{array}{l}\text { Primary not } \\
\text { completed }\end{array}$ & 141 & 28.2 & 148 & 29.6 & 111 & 22.2 & 400 & 26.7 \\
\hline Primary completed & 45 & 9.0 & 135 & 27.0 & 173 & 34.6 & 353 & 23.5 \\
\hline $\begin{array}{l}\text { Secondary school } \\
\text { not completed }\end{array}$ & 74 & 14.8 & 181 & 36.2 & 138 & 27.6 & 393 & 26.2 \\
\hline \multicolumn{9}{|l|}{ Religious affiliation } \\
\hline Christianity & 60 & 12.0 & 296 & 59.2 & 357 & 71.4 & 713 & 47.5 \\
\hline Islam & 438 & 87.6 & 196 & 39.2 & 90 & 18.0 & 724 & 48.3 \\
\hline Traditional & 2 & 0.4 & 8 & 1.6 & 53 & 10.6 & 63 & 4.2 \\
\hline \multicolumn{9}{|c|}{ Parents, marital status } \\
\hline Never married & 18 & 3.6 & 33 & 6.6 & 15 & 3.0 & 66 & 4.4 \\
\hline Married & 350 & 70.0 & 202 & 40.4 & 207 & 41.4 & 759 & 50.6 \\
\hline Divorced & 33 & 6.6 & 56 & 11.2 & 58 & 11.6 & 147 & 9.8 \\
\hline Widowed & 73 & 14.6 & 57 & 11.4 & 108 & 21.6 & 248 & 16.5 \\
\hline Both dead & 10 & 2.0 & 60 & 12.0 & 80 & 16.0 & 150 & 10.0 \\
\hline Separated & 16 & 3.2 & 92 & 18.4 & 32 & 6.4 & 140 & 9.3 \\
\hline \multicolumn{9}{|c|}{ Parents' living arrangements } \\
\hline Living Together & 379 & 75.8 & 229 & 45.8 & 204 & 40.8 & 812 & 54.1 \\
\hline Living Separately & 38 & 7.6 & 145 & 29.0 & 71 & 14.2 & 254 & 16.9 \\
\hline Don't Know & 83 & 16.6 & 126 & 25.2 & 225 & 45.0 & 434 & 28.9 \\
\hline \multicolumn{9}{|c|}{ Parents' marriage types } \\
\hline Monogamous & 207 & 41.4 & 284 & 56.8 & 281 & 56.2 & 772 & 51.5 \\
\hline Polygynous & 293 & 58.6 & 216 & 43.2 & 219 & 43.8 & 728 & 48.5 \\
\hline \multicolumn{9}{|l|}{ Income per week } \\
\hline Less than \# 100 & 222 & 44.4 & 10 & 2.0 & 30 & 6.0 & 262 & 17.5 \\
\hline
\end{tabular}




$\begin{array}{lllllllll}\# 100-\# 500 & 269 & 53.8 & 207 & 41.4 & 295 & 59.0 & 771 & 51.4 \\ \text { \#50I and above } & 09 & 1.8 & 283 & 56.6 & 175 & 35.0 & 467 & 31.1 \\ \text { Mean } & \# 133.49 & & \# 1052 & & \text { \#759.40 } & & \# 651.89\end{array}$

Father's occupation

\begin{tabular}{|c|c|c|c|c|c|c|c|c|}
\hline Farming & 388 & 77.6 & 97 & 19.4 & 148 & 29.6 & 633 & 42.2 \\
\hline Trading & 45 & 9.0 & 145 & 29.0 & 54 & 10.8 & 244 & 16.3 \\
\hline Artisan & 26 & 5.2 & 43 & 8.6 & 168 & 33.6 & 237 & 15.8 \\
\hline Teaching & 06 & 1.2 & 11 & 2.2 & 14 & 2.8 & 31 & 2.1 \\
\hline $\begin{array}{l}\text { Other Government } \\
\text { workers }\end{array}$ & 26 & 5.2 & 175 & 35.0 & 34 & 6.8 & 235 & 15.6 \\
\hline $\begin{array}{l}\text { Private sector } \\
\text { workers }\end{array}$ & 09 & 1.8 & 23 & 4.6 & 24 & 4.8 & 56 & 3.7 \\
\hline Others & - & - & 06 & 1.2 & 58 & 11.6 & 64 & 4.3 \\
\hline \multicolumn{9}{|l|}{ Type of house } \\
\hline A single room & 115 & 23.0 & 225 & 45.0 & 174 & 34.8 & 514 & 34.3 \\
\hline A room and a Parlour & 319 & 63.8 & 180 & 36.0 & 184 & 36.8 & 683 & 45.5 \\
\hline A flat & 31 & 6.2 & 70 & 14.0 & 46 & 9.2 & 147 & 9.8 \\
\hline A duplet & II & 2.2 & 25 & 5.0 & 19 & 3.8 & 55 & 3.6 \\
\hline Others & 24 & 4.8 & - & - & 77 & 15.4 & 101 & 6.7 \\
\hline \multicolumn{9}{|l|}{ Children ever born } \\
\hline Less than 4 & 152 & 30.4 & 50 & 10.0 & 158 & 31.6 & 360 & 24.0 \\
\hline $4-8$ & 140 & 28.0 & 384 & 76.8 & 225 & 45.0 & 749 & 49.9 \\
\hline $9-13$ & 132 & 26.4 & 58 & 11.6 & 94 & 18.8 & 284 & 18.9 \\
\hline $14-18$ & 54 & 10.8 & 06 & 1.2 & 10 & 2.0 & 70 & 4.7 \\
\hline $19-23$ & 19 & 3.8 & 02 & 0.4 & 05 & 1.0 & 26 & 1.7 \\
\hline 24 and above & 03 & 4.8 & - & - & 08 & 1.6 & $\mathrm{II}$ & 0.7 \\
\hline
\end{tabular}

Street children's experiences, social supports received from the community members, NGOs and Social Welfare Department

Street children reported a range of experiences and supports. Many (44.9\%) children reported positive experiences of assistance and support from community members while $31.4 \%$ of the children reported that the community members were indifference to their plights. The supports received from community members include feeding $(24.9 \%)$, accommodation $(24.5 \%)$, counselling $(18.1 \%)$ and clothing
(I5.9\%). Life impacting supports such as education and health supports were rarely given to the street children (see Table 2). Few of the children (7.1\%) were aware of the existence of NGOs and majority (52.0\%) did not receive any form of assistance from government agency. Remand Homes are seen as typical Nigerian prisons, from which escape is desirable while support for access to formal health care was difficult. Table 2 shows the details of various supports received by the children from community members, NGOs and Social Welfare Department across the three cities selected for this study.

Table 2 Attitudes and support of the community reported by children 'of' the street

\begin{tabular}{|c|c|c|c|c|c|c|c|c|}
\hline \multirow{3}{*}{$\begin{array}{l}\text { Attitudes of the } \\
\text { community to the } \\
\text { street children }\end{array}$} & \multicolumn{6}{|c|}{ Town of Residence } & \multirow{2}{*}{\multicolumn{2}{|c|}{ Total }} \\
\hline & \multicolumn{2}{|c|}{ Kaduna } & \multicolumn{2}{|c|}{ Lagos } & \multicolumn{2}{|c|}{ Port Harcourt } & & \\
\hline & $\bar{N}$ & $\%$ & $\mathrm{~N}$ & $\%$ & $\mathrm{~N}$ & $\%$ & $\mathrm{~N}$ & $\%$ \\
\hline $\begin{array}{l}\text { Accommodative } \\
\text { Hostile } \\
\text { Indifference }\end{array}$ & $\begin{array}{l}60 \\
05 \\
39\end{array}$ & $\begin{array}{l}56.6 \\
5.8 \\
37.6\end{array}$ & $\begin{array}{l}61 \\
160 \\
99\end{array}$ & $\begin{array}{l}19.0 \\
50.0 \\
31.0\end{array}$ & $\begin{array}{l}132 \\
34 \\
57\end{array}$ & $\begin{array}{l}59.0 \\
15.4 \\
25.6\end{array}$ & $\begin{array}{l}253 \\
199 \\
195\end{array}$ & $\begin{array}{l}44.9 \\
23.7 \\
31.4\end{array}$ \\
\hline Total & 104 & 100.0 & 320 & 100.0 & 223 & 100.0 & 647 & 100.0 \\
\hline
\end{tabular}

Assistance received from the community 


\begin{tabular}{|c|c|c|c|c|c|c|c|c|}
\hline $\begin{array}{l}\text { Accommodation } \\
\text { Feeding } \\
\text { Clothing } \\
\text { Health service } \\
\text { Education } \\
\text { Counseling } \\
\text { Others }\end{array}$ & $\begin{array}{l}95 \\
100 \\
97 \\
50 \\
10 \\
80 \\
-\end{array}$ & $\begin{array}{l}22.0 \\
23.1 \\
22.5 \\
11.6 \\
2.3 \\
18.5 \\
-\end{array}$ & $\begin{array}{l}65 \\
133 \\
62 \\
12 \\
32 \\
122 \\
47\end{array}$ & $\begin{array}{l}13.7 \\
28.1 \\
13.1 \\
2.5 \\
6.8 \\
25.8 \\
9.9\end{array}$ & $\begin{array}{l}150 \\
83 \\
43 \\
30 \\
14 \\
28 \\
15\end{array}$ & $\begin{array}{l}41.3 \\
22.9 \\
11.8 \\
8.3 \\
3.9 \\
7.7 \\
4.1\end{array}$ & $\begin{array}{l}310 \\
316 \\
202 \\
92 \\
56 \\
230 \\
62\end{array}$ & $\begin{array}{l}24.5 \\
24.9 \\
15.9 \\
7.3 \\
4.4 \\
18.1 \\
4.9\end{array}$ \\
\hline Total & *432 & 100.0 & *473 & 100.0 & *363 & 100.0 & $* \mid 268$ & 100.0 \\
\hline \multicolumn{9}{|c|}{ Awareness of NGOs providing Assistance to the children } \\
\hline $\begin{array}{l}\text { Yes } \\
\text { No }\end{array}$ & $\begin{array}{l}04 \\
100\end{array}$ & $\begin{array}{l}3.4 \\
96.6\end{array}$ & $\begin{array}{l}06 \\
314\end{array}$ & $\begin{array}{l}2.0 \\
98.0\end{array}$ & $\begin{array}{l}36 \\
197\end{array}$ & $\begin{array}{l}16.0 \\
84.0\end{array}$ & $\begin{array}{l}46 \\
611\end{array}$ & $\begin{array}{l}7.1 \\
93.0\end{array}$ \\
\hline Total & 104 & 100.0 & 320 & 100.0 & 223 & 100.0 & 647 & 100.0 \\
\hline \multicolumn{9}{|c|}{ Assistance received from the NGOs } \\
\hline $\begin{array}{l}\text { Accommodation } \\
\text { Feeding } \\
\text { Clothing } \\
\text { Health service } \\
\text { Education } \\
\text { Counselling } \\
\text { Others } \\
\text { (Vocational Training) }\end{array}$ & $\begin{array}{l}- \\
05 \\
04 \\
02 \\
- \\
04 \\
06\end{array}$ & $\begin{array}{l}- \\
23.0 \\
19.0 \\
9.0 \\
- \\
19.0 \\
28.0\end{array}$ & $\begin{array}{l}02 \\
09 \\
09 \\
04 \\
09 \\
10 \\
10\end{array}$ & $\begin{array}{l}3.8 \\
17.0 \\
17.0 \\
7.5 \\
17.0 \\
18.9 \\
18.9\end{array}$ & $\begin{array}{l}11 \\
77 \\
32 \\
10 \\
32 \\
73 \\
36\end{array}$ & $\begin{array}{l}4.1 \\
28.4 \\
11.8 \\
3.7 \\
11.8 \\
26.9 \\
13.3\end{array}$ & $\begin{array}{l}13 \\
94 \\
45 \\
16 \\
41 \\
97 \\
156\end{array}$ & $\begin{array}{l}2.8 \\
20.3 \\
9.7 \\
3.5 \\
8.9 \\
21.0 \\
33.8\end{array}$ \\
\hline Total & $* 21$ & 100.0 & *53 & 100.0 & *27I & 100.0 & *462 & 100.0 \\
\hline \multicolumn{9}{|c|}{ Assistance received from Social Welfare Department } \\
\hline $\begin{array}{l}\text { Accommodation } \\
\text { Feeding } \\
\text { Clothing } \\
\text { Health service } \\
\text { Education } \\
\text { Counseling } \\
\text { None } \\
\text { Others }\end{array}$ & $\begin{array}{l}- \\
02 \\
01 \\
01 \\
- \\
03 \\
101 \\
-\end{array}$ & $\begin{array}{l} \\
1.8 \\
0.9 \\
0.9 \\
- \\
2.8 \\
93.5 \\
-\end{array}$ & $\begin{array}{l}74 \\
90 \\
75 \\
70 \\
74 \\
65 \\
279 \\
06\end{array}$ & $\begin{array}{l}10.1 \\
12.3 \\
10.2 \\
9.6 \\
10.1 \\
8.9 \\
38.0 \\
0.8\end{array}$ & $\begin{array}{l}04 \\
10 \\
11 \\
06 \\
05 \\
09 \\
198 \\
25\end{array}$ & $\begin{array}{l}1.2 \\
3.3 \\
3.5 \\
2.3 \\
2.1 \\
3.1 \\
65.3 \\
8.3\end{array}$ & $\begin{array}{l}78 \\
102 \\
87 \\
78 \\
79 \\
77 \\
578 \\
32\end{array}$ & $\begin{array}{l}7.0 \\
9.2 \\
7.8 \\
7.0 \\
7.1 \\
6.9 \\
52.0 \\
2.8\end{array}$ \\
\hline Total & * 108 & 100.0 & *733 & 100.0 & *303 & 100.0 & * IIII & 100.0 \\
\hline
\end{tabular}

*Multiple responses were received

The composite score index of social support received from the different stakeholders by the street children were calculated based on the children's ranking. The value of this composite score index were used to describe the situation of the street children across the different locations selected for this study. Six different indices were used in computing the composite score index. These are accommodation, feeding, clothing, health services, education and counselling. The composite score index was computed by assigning ' $I$ ' to the respondent's answer where it is 'Yes' (i.e. where the respondent claimed to receive support in a particular area) and ' 0 ' where the answer is 'No', while the mean of the overall result was taken to be the composite score of the available social support network. The use of ANOVA was employed to compare the mean levels of supports received by the children 'of' the street of various social descriptions. This was to ascertain whether the mean index of support differs significantly across the stakeholders. Where $\mathrm{P}<0.0 \mathrm{I}$ or $\mathrm{P}<0.05$, the differences in the levels of support received is assumed to be statistically significant, and otherwise where $\mathrm{P}>0.05$.

Table 3 presents data on the ranking of the different support providers according to levels of importance attached to them by the street children. In the total sample, the street children ranked the homeless adult on the street as most important, the community members as second and Civil Society Organisations as third. The NGOs were ranked fourth, while the Government Agencies were least important. This implies that the homeless adults on the street seem to be the role model for the street children. This has serious implication for the future of the country, for such associations could lead to the proliferation of street gangs.

Table 3 Street children' ranking of the support provided by support providers

\begin{tabular}{|c|c|c|c|c|c|c|c|}
\hline \multirow[t]{2}{*}{ Support providers } & \multicolumn{5}{|c|}{ Town of Residence } & \multirow[t]{2}{*}{ Total } & \multirow[t]{2}{*}{ Mean $(\mathrm{N})$} \\
\hline & Kaduna & Mean $(\mathrm{N})$ & Lagos & Mean $(\mathrm{N})$ & $\begin{array}{l}\text { Port Harcourt } \\
\text { Mean }(\mathrm{N})\end{array}$ & & \\
\hline Government Agencies & 2.0552 & & 1.8896 & $(3 \mid 3)$ & $1.3232(190)$ & $\mid .775$ & $(606)$ \\
\hline
\end{tabular}




\begin{tabular}{lllll} 
NGOs & $1.9980(102)$ & $1.3183(312)$ & $2.1853(188)$ & $1.8175(603)$ \\
\hline Community members & $4.8277(104)$ & $2.1660(308)$ & $2.6095(198)$ & $3.2367(614)$ \\
\hline Civil Society Organisations & $2.1649(101)$ & $1.9979(308)$ & $2.5530(194)$ & $2.2279(604)$ \\
\hline Homeless Adults on the street & $3.1697(102)$ & $2.2731(291)$ & $4.3843(193)$ & $3.2553(593)$
\end{tabular}

\section{Perception of street children by service providers and community members}

In this section we report on perceptions of street children by adults, including service providers, community leaders, and ordinary Nigerians.

\section{Street children's vulnerability to trafficking in Nigeria}

Trafficking has become a very serious problem in Nigeria and raising a serious security concern both at the national and international levels. Although various categories of people are vulnerable to trafficking, the case of street children needs special attention as they are more vulnerable to the problem more than other categories of people. This is because they have a range of problems which predispose them to human trafficking. They are still young and immature to take reasonable and responsible decision and at the same time lack care from any responsible adult, they are homeless, and lack feeding, health and clothing. This study also shows that the Social Welfare Department charged with the responsibility of supporting the children in Nigeria has failed, as their practices are still based on traditional punitive measures for correcting juvenile delinquency. Children see Remand Homes as a place of 'punishment' rather than 'support'. These predispose them to frequent and unchallenged abuse from police and community members. Evidence from this study suggests that street children are being trafficked by some community members who pretend to give them various assistances while some street adults also act as syndicates and intermediary in trafficking street children. Some key informants and interview with NGOs affirmed that;

"Once those with hidden motives are successful in deceiving a street child as his/her long awaited "messiah", they quickly traffic them for various purposes to various destinations. Since children of the street have nobody to ask for their whereabouts, they are more vulnerable than children on the street but both of them are vulnerable to being kidnapped for various purposes". In-depth interview with Government Agency, Lagos

"In some cases street children were only accommodated by some people so that they could be used as a cheap labour for domestic works or even for the purpose of using them for trafficking or rituals". FGD with Opinion Lead- ers, Males - Lagos

"There are those who assist the street children out of sincere heart while some have ulterior motives for doing so". FGD with Adult Females - Kaduna

"Street children face a lot of problems on the street. They are abused and even used for rituals by the rich and wicked people in the society". FGD with Opinion Leaders, Females Kaduna

"The condition of the street children is pathetic because they are battered on every side and by all categories of people in the society. The police abuse them, the community members stigmatize and molest them, and they face a lot of problems with their colleagues and are at risks of abuse and falling to the hand of traffickers through the adults who are on the street like them". Interview with Non-Governmental Organisation, Lagos

\section{Street children and drug use}

The use of illicit drugs and trafficking of drugs are other problems threatening security at local and international levels. Illicit drugs use and trafficking is proving resilient to all remedial actions across the globe. One of the various factors responsible for difficulties in curbing drug use and trafficking is the apparently increasing use of street children by the drug trade. Evidence from this study suggests that street children in Nigeria are involved in drug use and are used for drug trafficking purposes. These report range from sympathetic comments, to neutral observations, to blanket accusations and condemnation of all street children, reflecting the ambivalent attitude towards street children, and how to "deal with" them. Some key informants and FGD participants noted;

"Many street children smoke Indian hemp and take all sorts of hard drugs to cope with street life". FGD with Adult Males Kaduna

"Most street children cope with street life by involving themselves in crime and hard drugs". In-depth interview with an Imam - Lagos "Most street children here in Lagos are notorious for crime for their survival. They are involved in theft, burglary and even aiding the drug pushers (drug traffickers). There is rarely any form of crime in which street children are not involved". FGD Adult Females, Lagos 
"Typical street children will have no mother to take care of them or any father to advise them. They are left on their own to work. They are involved in menial jobs such as pushing of wheelbarrows, carrying loads for market women and of course most of the times take to crime like stealing, robbery, illicit drug use and aiding drug traffickers in order to survive". In-depth Interview with Government Agency - Port Harcourt

\section{Street children and violence in urban Nigeria}

Nigeria's position as the most populous in the continent of Africa and the spate of sectarian, political and resource/oil-related violence and lack of security of lives and properties in some regions of the country calls for urgent attention. Some respondents asserted that "there is rarely any violent crime within the country in which street children are not involved". Some key informants and FGD participants expressed that;

"Street children are used for religious riots to cause violence and kill Christians in the North. The Islamic fundamentalists and religious fanatics take advantage of their situation. Once they are given N20 or N50, they are ready to do anything because they are hungry. Their mallams also always indoctrinate them that if they die in the course of fighting for Allah, they will get to heaven". In-depth interview with a Pastor Kaduna

"The street children get themselves involved in stealing, causing violence because they take advantage of violence to rob people. They remove people's handsets and engage in pocket picking for their daily bread. They join hands with armed robbers. They are 419". In-depth Interview with a Pastor - Lagos

"Street children are very notorious. I have had some encounter with them. They pick pocket and rob people. They are merciless and create crisis so that they could use the opportunity to rob people of their properties. The government must do something to eradicate them". FGD with Adult Women, Lagos

"If there are no street children, the rate of crime will be very minimal because they are the most dangerous agent of crime. They are involved in every form of crime for a living while they are also ready instrument of violence in the hand of the politicians". FGD with Male Opinion Leaders - Lagos

"Many street children do not have a place of abode; they sleep under the bridge, market places and in uncompleted buildings. They also lack parental upbringing and have no financial assistance anywhere, hence they take to all sort of dirty jobs and violence crime in Nigerian urban centres to survive". In-depth interview with Government Agency, Port Harcourt

These and many other uncomplimentary and sometimes sympathetic statements were used to describe street children across the three urban centres selected for this study in Nigeria.

\section{Discussion}

This study reports on real and perceived links between persistent high numbers of street children, human trafficking and national and human security threats through drug trafficking, and violence.

Children, including street children, are minors who need responsible adults to ensure not just survival but healthy and safe development. Evidence from the literature suggests that most street children are in the age group of $9-14$ years. The UNICEF Child Domestic Labour Workshop (1998) noted that children as young as 6 years old may be found in street trading but most are between 9 and 14 years old. The children come from poor and overcrowded homes. Lacking care and support from responsible adults, they are vulnerable to exploitation by adult members of the society. This further makes them vulnerable to human trafficking and various abuses that could predispose them to HIV/AIDS infection, drug addiction, violence, and imprisonment. All these conditions amount to the abuse of the children's fundamental human rights and a violation of the Convention for the Rights of the Child, 1989. Yet adults in the community make worrying and frequent statements labelling the children themselves as the main problem and calling for their "eradication". Efforts at addressing the human rights of the children in Nigeria needs to focus not on eradicating street children, but on government policies on poverty eradication and other policies relating to the provision of basic needs of life to every family, the absence of which leads to the abuse of children's fundamental human rights.

Both street children themselves and adults in the community report that street children are battered on every side, by the community members, security agents, adults on the streets as well as their peers. They are vulnerable to trafficking for various purposes, which is one of the problems threatening global human security and a fundamental issue on the abuse of human rights of people across the globe. Street children are also used by religious fundamentalists as well as the politicians as instrument of violence in urban cities in Nigeria. It is sad to note that the condition of most street children in Nigeria have not improved despite the enactment of the child 
rights acts 2003. The children are still subjected to various kinds of abuses while they also perpetrate crime in order to cope with street life making relevant the strain theory (Agnew, Brezina, Wright, \& Cullen, 2002; Aseltine, Gore, \& Gordon, 2000; Baron, 2004; Broidy, 200 I; Joon Jang, 2007) and lifestyle activity theory . In order to guarantee the human rights of the street children in Nigeria therefore, there is need for the government to provide adequate protection programmes for them. This calls for the overhauling and strengthening of the relevant government agencies which are in charge of support programme for the children in Nigeria. At present, the services provided by the Department are unattractive to the street children. This also questions the integrity and commitment of the Nigerian government to the implementation of the Nigerian Child Rights Acts 2003, which is a precondition for upholding the children's fundamental human rights in the country. Contrary to earlier findings that majority of street children come from polygamous families (Aderinto, 2000; Oloko, 1999), this study found that more than half of the children are from monogamous homes, although many other basic characteristics of the children remain the similar. This means that while polygyny as a form of marriage may still be contributing to this problem, there are many other problems within the monogamous homes contributing to children working and/or living on the street. It is also important to note that the children's parents characteristics is no longer confined to uneducated parents but some children of civil servants, although at the lower level cadres were being increasingly found among the Nigerian street children as evidenced in this study.

The limitation of this study lies in the inability to generalize the findings due to the sampling methods employed, it is important to point out that the study however provides a synthesis of perspectives on street children from important stakeholders in Nigeria. It also helps to understand the preference of the children themselves in terms of sources of supports and assistance. Since street children see street gangs as role models, it thus becomes imperatives for strategies to identify and co-opt some already reformed street gangs, who could serve as links to reach the children for better results.

\section{Conclusion}

This paper documented the experience of street children and other stakeholders' perceptions and rhetorics around street children in Nigeria. Street children are perceived to be vulnerable to exploitation and abuse. They are also at high risk for contracting and spreading HIV as a result of sexual victimization, yet are also widely perceived to be involved in both petty and serious crime. In Nigeria, stakeholders increasingly express concerns that street children are used as drug mules within and beyond Nigeria, pressed into commercial sex within and beyond Nigeria, and manipulated or bribed into the fire-bombings and other violence characterizing sectarian violence and terror in Nigeria. While some stakeholders urge increased protection of child rights and stronger action against the forces pulling or pushing children into the streets and against those who traffic and exploit children, others urge that the street children be "eradicated". In this paper we report on a study of street children in three major cities in Nigeria. This study raised the questions at the centre of our new work and offers insights into the contradictory experiences, rhetorics, and interventions which seek both to "deal with" the "problem" of street children and to protect the rights and welfare of these children. We emphasize the need for more pragmatic steps by the Nigerian government and civil society to address both the factors driving the increasing numbers of street children and the conditions faced by street children if human trafficking and security problems of the country are to be addressed and the fundamental human rights of her citizens, especially children, guaranteed.

Finally, it is also important to address access to justice: that all categories of disadvantaged people including street children in Nigeria have access to free or affordable legal services, and that these should be coupled with an effective and protective police and judicial system.

\section{References}

Aderinto, A. A. (2000). Social Correlates and coping strategies of street-children: a comparative study of street and non-street children in South-

Western Nigeria. Child Abuse and Neglect, 9, II99-1213.

Agnew, R. (200I). Building on the Foundation of General Strain Theory: Specifying the Types of Strain Most Likely to Lead to Crime and Delinquency. Journal of Research in Crime and Delinquency, 38(4), 319-36।. doi: |0.1 I77/ 0022427801038004001

Agnew, R., Brezina, T., Wright, J. P., \& Cullen, F. T. (2002). STRAIN, PERSONALITY TRAITS, AND DELINQUENCY: EXTENDING GENERAL STRAIN THEORY. Criminology, 40(I), 43-72. doi: I0.1 III/j. I745-9|25.2002.tb00949.x

Ahiante, A. (2004). "Soccour for street children". This Day, March 23.

Aransiola, J. O., \& Agunbiade, M. O. (2009). Coping Strategies of Street Children in Nigeria. Journal of 
Social and Psychological Sciences. Oxford Mosaic Publications Limited, 2(2).

Aransiola, J. O., Bamiwuye, S. O., Akinyemi, A. I., \& Ikuteyijo, L. O. (2009). Proliferation of Street Children in Nigeria: Issues and Challenges. Journal of Social Work, 9(4), 37I-385.

Araoye, M. O. (2006). Female Adolescent hawkers in Nigeria: HIV/AIDS related Knowledge, Attitudes and Behaviour. Journal of Community Medicine and and Primary Health Care, I6(2), 2329.

Aseltine, R. H., Jr., Gore, S., \& Gordon, J. (2000). Life Stress, Anger and Anxiety, and Delinquency: An Empirical Test of General Strain Theory. Journal of Health and Social Behavior, 4 I (3), 256-275. doi: 10.2307/2676320

Baron, S. W. (2004). GENERAL STRAIN, STREET YOUTH AND CRIME: A TEST OF AGNEW'S REVISED THEORY*. Criminology, 42(2), 457-484. doi: I0.1 I I I/j. I745-9|25.2004.tb00526.x

Bourdillon. (200I). "The children on our streets". Reading for youth and childcare workers $(35$, December 200I).

Broidy, L. M. (200I). A TEST OF GENERAL STRAIN THEORY*. Criminology, 39(I), 9-36. doi: I0.1IIII/ j. I745-9125.200I.tb009I5.x

Clark, M. A. (2003). Trafficking in Persons: An issue of human security. Journal of Human Development, 4(2), 247-263. doi: 10.1080/ I 464988032000087578

Cohen, L. E., \& Felson, M. (1979). Social Change and Crime rate trends: A routine activities approach. American Sociological Review, 44, 588-608.

Dave-Odigie, C. P. (2008). Human Trafficking Trends in Nigeria and Strategies for Combating the Crime. Peace Studies Journal, I (I, Fall).

Federal Government of Nigeria. (2003). Nigerian Child Rights Acts 2003 Enacted by the National Assembly of Federal Republic of Nigeria. Enter into force on 14th July 2003.

Federal Republic of Nigeria. (2003). TRAFFICKING IN PERSONS (PROHIBITIION) LAW ENFORCEMENT AND ADMINISTRATION ACT, (2003) 2003 ACT NO. 24. . ENACTED by the National Assembly of the Federal Republic of Nigeria. Enter into force on [1 4th July, 2003].

Fitzgibbon, K. (2003). MODERN-DAY SLAVERY? African Security Review, I2(I), 8I-89. doi: 10.1080/10246029.2003.9627573

Fitzpatrick, J. (2002). Trafficking and a Human Rights Violation: The Complex Intersection of Legal Frameworks for Conceptualizing and Combating Trafficking; . Journal of International Law I /43, 1143 - II68.

Hindelang, M. J., Gottfredson, M. R., \& Garofalo, J. (1978). Victims of Personal Crime: Empirical
Foundation for a Theory of Personal Victimization, . Ballinger, Cambridge, Mass. Joon Jang, S. (2007). Gender Differences in Strain, Negative Emotions, and Coping Behaviors: A General Strain Theory Approach. Justice Quarterly, 24(3), 523-553. doi: 10.1080/ $074|882070| 485486$

Keefer, S. L. (2006). Human Trafficking and the Impact on National Security in the United States Available at: www.strategicstudiesinstitute.army.mil.

Le Roux, J. (1996). "Street children: A "man-made" phenomenon". Journal of Pedagogics, I6(I), 3I-39.

Makinwa-Adebusoye, P. (2006). Hidden: A Profile of Married Adolescents in Northern Nigeria Available at: http://www.actionhealthinc.org/ publications/docs/hidden.pdf.

Ojukwu, A. (2006). Human Trafficking. . Daily Champion Sep 21., Available at: http:// www.stopdemand.org/afawcsO I / 2878/ $I D=0|| 2 \mid 80 /$ newsdetails.html

Oloko, S. B. A. (1999). Child labour: the hidden workforce - children domestic labour. The Progress of Nigerian Children, 48-5I.

Sampson, R. J., \& Lauritsen, J. L. (1990). Deviant Lifestyles, Proximity to Crime, and the OffenderVictim Link in Personal Violence. Journal of Research in Crime and Delinquency, 27(2), II0I39. doi: 10. I I77/0022427890027002002

UNESCO. (2006). Human Trafficking in Nigeria: Root Causes and Recommendation. UNESCO Policy Document. Policy paper poverty series. Paris, France.

UNICEF. (2005). At a Glance: Nigeria. Nigeria Officials Rescue more than 100 children from Child Traffickers. Available at: http:// www.unicef..org/infobycountry/images/ ibc_nigeria_25508_pic/2.jpg

UNICÉF. (2007). At a glance: Nigeria. Digital Diary; Nigerian Street Children tell their stories of life without security. Available at: $h t t p: / /$ www.unicef.org/people/nigeria_42282.html.

UNICEF Child Domestic Labour Workshop. (1998). UNICEF, Child Domestic Labour and Trafficking in West and Central Africa, July 1998. . Available at: http://www.globalmarch.org/worstformsreport/ world/domesticchildservitude.html.

United Nations (UN). (1957a). Abolition of Forced Labour Convention, (1957) (No. 105). Adopted on 25 June 1957 by the General Conference of the International Labour Organisation at its fortieth session. Entry into force: 17 January 1959, in accordance with article 4. Available at: http://www2.ohchr.org/english/law/abolition.htm.

United Nations (UN). (1957b). Supplementary Convention on the Abolition of Slavery, the Slave 
Trade, and Institutions and Practices Similar to Slavery. . Adopted by a Conference of

Plenipotentiaries convened by Economic and Social Council resolution 608(XXI) of 30 April 1956 and done at Geneva on 7 September 1956. Entry into force: 30 April 1957, in accordance with article 13. , Available at: http://www2.ohchr.org/english/law/ slavetrade.htm.

United Nations (UN). (1989). Convention on the Rights of the Child. Adopted and opened for signature, ratification and accession by General Assembly resolution 44/25 of 20 November 1989. Entry into force 2 September 1990, in accordance with article 49. Availabe at: http:// www2.ohchr.org/english/law/crc.htm.

United Nations (UN). (1999). Worst Forms of Child
Labour Convention, 1999 (No. 182). . Adopted on 17 June 1999 by the General Conference of the International Labour Organization at its eightyseventh session. Entry into force: 19 November 2000, in accordance with article 10., Available at: http://www2.ohchr.org/english/law/childlabour.htm.

United Nations (UN). (200I). Protocol to Prevent, Suppress and Punish Trafficking in Persons, Especially Women and Children, . Supplementing the United Nations Convention Against

Transnational Organized Crime, G.A. Res. 25, annex II, U.N. GAOR, 55th Sess., Supp. No. 49, at 60, U.N. Doc. A/55/49 (Vol.I) (200I), entered into force Dec. 25, 2003., Available at: http:// wwwl.umn.edu/humanrts/instree/trafficking.html. 